\title{
Higher education and graduate employment in Albania
}

\author{
Armanda Keqi \\ akeqi@epoka.edu.al \\ Epoka University
}

\begin{abstract}
In the social and economic transition, the Higher Education in Albania has tremendously ocercomed its capacities and the opportunities offered. Albania is considered the champion country in Europe for the high number of universities. Besides the public universities, in the country also operate dozens of private universities. in Albania there are about 20 universities per million inhabitants, (161500 students for a population of 2,8 million people), nearly eight times more than countries like UK that have internationalized higher education and have a very large percentage of foreign students. This paper takes into account the development of higher education and the responsible institutions of this development during the transition in Albania, the current structure of universities, the financial problems and the reform of higher education. It also examines issues such as: the measurement of quality, the ranking and the competition between public universities and private institutions. Then the focus of the paper runs on the employment of the young graduates who have finished albanian universities in the last five years. Firstly, relying on foreign literature, I have analyzed some of the main models of employment of graduates, their skills in the labor market, and also the changes that have occurred in the careers of the graduates in the last century. for the extraction of data are used questionnaires distributed electronically to over 230 employees that have brought significant conclusions about the employment of graduates in Albania, as well as the impact of such factors as: GPA, the training, the number of foreign languages spoken and other qualifications and skills that affect the level of salary and their position at work. Also starting from the above models, the scope is to identify the key elements that affect the careers of albanian graduates, and the key factors that have driven their employment. In the end of the paper are given some conclusions and recommendations on how higher education in Albania should be reformed, given by the sample responses of the interviewers, but also by a concrete analysis of the problems that are facing this sector in Albania, and how this reformation of higher education can increase its fruits on more qualified and employed youths in their respective fields. The methodology used is mainly from primary sources, ranging from the data collected by the respondents, as well as from secondary sources of data published for this area of study. The main limitation of such a work is the limited number of samples under the survey, the data of whom has been generalized for all the population of the paper.
\end{abstract}

Keywords: Higher education, private university, reform, graduate employment, skills, career

\section{Literature review}

The 21st century of work can be described as a quick and variable environment that sets high levels of pressure on them that act in this context. (Fugate, M \& Kinicki, A.J, 2008). Today's economic climate reflects flexibility, volatility, creativity and adaptability (Van der Heljden, 2002), skills that are not traditionally required for a successful career. It is widely known that employees today do not only hire based on the level of education. ( Stewart \& Knoëles, 1999; Archer \& Davison, 2008, Nilsson, 2010)

Youth employment is largely a problem that affects every society and societies largely still fragile economy and high unemployment rates, as is our society. However it has also skeptics who argue that employment is not more than " the last movement of the world "Employment is generally described as the ability to gain meaningful employment (Clarke M. , 2008). However each person becomes more and more aware of the importance of learning and the role of institutions of higher education regarding employment. ( Van der Heijden, 2009) (Clarke M. , 2008). Employment especially of the youths one is a problem that affects every society and largely societies that have still fragile economy and high unemployment rates, as is our society. However it has also skeptics who argue that employment is not more than "the last movement of the world " (Clarke M. , 2008). However each person becomes more and more aware of the importance of learning and the role of institutions of higher education regarding employment (Van der Heijden, 2009). Increasingly policy makers are focusing on employment of graduates as a key indicator in making choices in terms of education level (Dias de Oliveira, $\mathrm{E}$. \& de Castro Gulmaraes, I , 2010). Overall employment of students and, moreover, the availability of graduates willing to work has been the focus of labor market and policy makers in the last decade. (Brown, P., Hesketh, A. \& Williams, S, 2003). Governments and employers are realizing the importance of combining knowledge, skills, and efforts of individuals in building a sustainable competitive advantage (Brown, 2003). 
Employees are increasingly directed to HEl-s with the hope to provide graduate students who are well-rounded individuals, aware of their own knowledge and with all the attributes required in a position to be distinguished since the beginning of employment (Little, 2011). These last or organizations themselves, already require individuals who are suitable, creative, innovative, flexible, and solving the acute problems ( Graduate Market Trends, 2010). When it comes to secure a job, the individual can not rely only to the degree level that has received (Yorke, 2006). (Yorke, M. and Knight, P, 2003) (Yorke, M. \& Knight, P.T , 2006) showed in their paper that having a diploma enables important simply to compete for a job, but employers choose among graduates based on "something more complex. "

(Harvey L. , 2005) in his review on employment, notes that "It is not only to find a job more than is in the developing, learning, and the emphasis is less on "employment" and more on the "skills". Despite the lack of scientific knowledge of how to agree on the meaning and contribution to employment factors (Brown, P., Heskesth, A. \& Williams, S., 2003), and it still have a wide acceptance as a suitable alternative on the concept employment (Clarke, M., 2008).

Students, regardless of the discipline of study usually have certain expectations about employment opportunities. Before they are concerned about their graduation and then they look after the options of employment. Although these expectations are unreasonably inaccurate as it came out from the search results (Psacharopoulos, 1987) students are very aware that where demand is very strong, there are differences in initial acquisitions, as a result of differences in the disciplines of study and higher rates of incomes growth for higher levels of diploma. Students therefore, tend to move to those areas and get those majors in which demand is high and where continued growth in demand is expected.

A study of EUNACAL Institute in February 2012, where 4.847 people were interviewed across the country, shows that the main reason why students of public and private universities have decided to attend university and their parents aspired so for their children growth are exactly employment opportunities for the future. The same study notes that the majority of young people now attend high school intending to continue their studies in the field of economy branches, architecture \& planning, informatics, dentistry and law. A study EUNACAL Institute in February 2012, where 4.847 people were interviewed across the country, shows that the main reason why students of public and private universities have decided to attend university and their parents aspired for so children their growth is exactly employment opportunities in the future. The same study notes that the majority of young people now attend high school intending to continue studies in the field of economy branches, architecture \& planning, informatics, dentistry and law (EUNACAL, 2012).

The main factors that affect pending employment or unemployment are: Expected revenue duration of work, field of study, level of education, gender, and the link between study and work tasks (Ama, 2008). Teichler (Teichler, 2000) in his study of higher education and work in Europe concluded that graduates appreciate their studies and believe that learning in higher education is helpful in coping with the jobs that they undertake. The graduates were of the opinion that higher education should prepare students to be better able to apply their knowledge about the environment in which they work and to cope with their job duties. So for the graduates 'job skills' become as necessary and important as education.

\section{Higher education in Albania}

"If knowledge is the electricity of a new international information economy, higher education institutions are the sources of energy in which the new development process must be supported." - Manuel Castells (1993)

Starting from the 1990's, higher education has gone through several significant stages with their positive and negative sides for its development. After the fall of communism, the period 1990-1994 was characterized slightly by the opening of the universities, where mostly the state dominates, and the university autonomy wasn't in a significant stage. Initially there were only two universities, and then also was well established the Polytechnic University, after its separation from the University of Tirana. Also existed in Tirana, three Academies (of Arts, Sports and Military), and in three regions (Shkoder, Elbasan, Gjirokastra) three Pedagogical Institutes and in Korce operated The Higher Institute of Agriculture. The research was conducted partially in universities, Institutes systems, and partially in The Academy of Sciences and in the Institutes under the departments located in Tirana and other cities. in 1992-93, Higher Education Institutions outside Tirana, were transformed into universities in these cities, respectively Elbasan, Shkodra and Korca. The years 1994 - '99 were characterized by further expansion of the higher education system and especially of the expansion of branches profiles on one hand and the university districts turned gradually to lose their identity and their specific profile. Still at this time private system was not a pressure on the public system, that's why the state system expanded more, but not equally with the economic development and the demand for certain professions.

The years 1999-2007 marked the opening of the first private institution of higher education. in 2001, the Ministry of Education orders the implementation of ECTS (European Credits Transfer System) in all HEI curricula in Albania. During 
this period, starting from 2002, were licensed the first private HEl-s, which operated until 2005, almost all specialized (Luarasi, Counsel "Zoja e Keshillit te Mire", New York University, Marubi, and Faculty of Dentistry of UFO's).

While in the years 2000-2005 there were only five private HEl-s, in the period 2005-2009 were opened 34 new private institutions and between the years 2009-2013 were opened also 10 other private HEI-s. During the transition period, but in particular from 2005 until today, there has been a rapid growth and expansion of the entire system of higher education, as both of the public and non-public institutions.

\section{Current Structure of Higher Education in Albania}

In the social and economic transition higher education in Albania has gone under a tremendous mass appeal capacities and opportunities offered. Currently Albanian system of Higher Education presents the following configuration: 59 Higher Education Institutions in total, 15 public and 44 private. Among them, 19 have the status university (12 public and 7 private), 5 have the college status (all private), 26 high schools (all private), 8 academies (two public and private 6 ), the first institution (public, center Inter-university) and 17 subsidiaries (HEI 5 public and 12 private HEl-s ). The number of programs offered in total is about 1500 of which 700 provided by public HEl-s and slightly less from private HEl-s and sorted by the level of study, approximately there are 650 in Bachelor, 250 in Master Professional, 350 in Master of Science, and about 100 third cycle programs and specializations in Ph.D. terms.

As reported by the international data, Albania has a large number of universities per 1,000 inhabitants compared with other developed countries. in Bangladesh there are about 20 universities per million inhabitants, nearly eight times more than countries like the UK that have internationalized higher education and have a very large percentage of foreign students. in terms of a country with 2.8 million inhabitants and an economy that invests no more than 40 million or $0.5 \%(0.4-0.6 \%)$ of its GDP on higher education, the figure is much higher

Ministry of Education have published 396 branches of private universities accredited by on 8th July 2013. Yet most of the students in Albania study at public universities (78.5\%). However the first number of students in private HEl-s had a very rapid growth particularly in the last 3-4 years, and secondly there has been an increasment in the part-time studies at the public universities, that today constitute about $21.5 \%$ of the total number of students in the public HEl-s. These two extensions have brought massive and even have declined somewhat the standard. in the recent years, programs profiled and the few professional programs focused primarily on the fields of nursing, economics, law, Social Sciences, Political etc. Albania invests several times less in higher education than its neighbors, and this investment is even incommensurable when comparisons are made with the most developed countries of Europe. The state budget has available about 38 million euros to support over 126,000 students in the state universities. This amount can be added to the approximately 20 million euros from secondary revenues provided by the universities themselves), so only about 460 euros per student in the public sector.

The budget for education in general, has never been higher than 3\% of the GDP limping in the intervals of $2.2-2.8 \%$ of GDP, while the objective suggested by UNESCO, UNDP, Millennium Goals, OECD, EU, etc, is at least $5 \%$ of GDP level (which means twice that currently allocates Albania). Western developed countries in the OECD framework of finance at levels $5-8 \%$ of their GDP university education, of which $1-3 \%$ of GDP goes directly to higher education and scientific research. Albania is currently spending on higher education $0.4-0.6 \%$ of GDP, as many joint state and private universities. So today Albania spends around 500-600 euros / student, while it needs at least 4-5 times more for to equate with Romania and Bulgaria, or 8-10 times more to be approached with Portugal, Spain etc. So, even taking into account our current conditions and opportunities, Albania should aim at least 1500-2000 euros figures / student, or in other words a budget of 250-350 million euros for its 161,500 students.

Today, professional higher education is almost negligible. Currently there are two private institutions that offer vocational programs of study, while in the public education there are three HEl-s with a total of 10 programs.

The next academic year 2014-2015 there will not be more part-time studies at university. Higher Education Commission, in the first draft report suggests the closure of part time studies at public universities and private, since it is considered as the "wound" of higher education in Albania. According to official data, only for the year 2004 -2005 the number of part-time students at public universities was about 20 thousand while today in public and private, they occupy one sixth of the total number of students in universities, over 31 thousand. 


\section{The problems in the Higher Education System today and the needs for Reforming}

Albania is considered the champion country across Europe to the high number of universities. Besides public universities in the country also operate dozens of private universities.

Quality Assurance System was created in 2001 by the Accreditation Agency, which developed especially after 2003, with the establishment of the Council of Accreditation. The procedures of development and the criteria for evaluation and the construction of this system were relatively slow compared with the rapid growth and the expansion of these institutions and the study programs. Here are presented some of the problems found in the system.

The structure had not and still does not have a strategy, policy development and a clear pattern of our Higher Education.

There hasn't been conducted an analysis for the employment and the development of higher education orientation towards these needs in the current or future market needs.

Development of higher education is characterized by a distorted development, reflected in the very large number of HEl-s, distribution of the study programs, where compatibility between real preference study students and performed studies is about $10 \%$.

in our HEl-s, today there are institutions and programs that work with the minimum number of students, which brings problems of financial inability to cover costs and ensure minimum standards of teaching, not to mention research or other activities.

Private System of Higher Education appears fragmented, there are 44 private $\mathrm{HEI}$-s that hold only $20 \%$ of the total number of students nationwide.

Many institutions which have the university status do not fulfill the institutional standards for this status. Inappropriate open subsidiaries.

Quality of HEl-s and study programs in the public system are not tested through the assessment and accreditation process Extensive expansion of part-time system.

Yet many university structures do not meet current standards of qualification, also due to their continued expansion.

Research as a key element of higher education institutions with university status, in Albania is very low, especially compared to European ones.

System and Foreign Internal Quality Assurance is characterized by problems and difficulties associated primarily with the knowledge and interest of $\mathrm{HEl}-\mathrm{s}$.

\section{Graduates and Employment}

\section{The current state of the labor market and graduates in Albania}

Various official data published by the Statistical Institute in Albania (INSTAT), have published that the vast majority of Albanians who have graduated in the last decade in the public and private universities have lost their jobs, while universities continue to produce degrees without employment prospects. INSTAT data shows that from 2001 to 2009,65 thousand Albanians completed high school, but meanwhile employment in the public and private sector grew by only 16 thousand people, showing that most of the graduates or are unemployed or have left the country and degrees are not worth anything.

In 2001, Albania had 394 thousand salaried employees in the non-agricultural sector, of which there were 189 thousand public sector employees and private sector employed 205 thousand people. in 2010, Albania had 410 thousand employees, of whom 167 thousand were in the public sector and 230 thousand in the private sector. This increase employment by 16 thousand people or less than 2 thousand jobs on average each year, is wholly inadequate to provide jobs for graduates, who seem to take very different degrees of the market needs.

Public universities have issued 60 thousand degrees from 2001 to 2009, of which, 12 thousand have been degrees in various branches of economics, 4500 in justice, and Polytechnic University of Tirana has graduated a total of 2,500 people, many of whom cars are engineering graduates, while for years, is the minimum number of graduates in electronic engineering, which is considered as the most perspective branch of today's world. in electronic engineering, Albania during this period has graduated 370 people, mostly in the period before 2005 , while post graduate this year are only 37 themselves. Graduates in the economy in the period 2000-2008 had significant chances of employment, which was caused 
by the fact that at this time Albania built banking and insurance sector. But after 2008, this sector appears to be "full", while the number of graduates is growing at high rates as a result of the opening of private universities.

Less future certainly looks to law graduates. in the last decade are 4500 graduates themselves, where regional universities have been very active. Meanwhile, thousands of others are waiting to get a degree in law in two to three years ahead. Is problematic in today's society, the fact that where jobs will find thousands of students who are currently studying in private universities, mostly in social sciences as economics, law or international relations often.

Albania is not doing any effective effort to encourage young people to enter career fields that have more perspective on the international market. Government projects or increasing internet penetration knowledge on computers and students are limited in their use, but not in software development. Albanians prefer traditional occupations, which would hardly be able to offer jobs. Agriculture University of Tirana, for example, graduates more people in Economics and Agricultural Policy than in Agribusiness farms, predicting that the agricultural policy-makers in the future will be more numerous than agricultural managers.

Official statistics show a high level of unemployment among young people and jobs more scarce, and the sector which is experiencing increased levels of employment and occupies important role in the youth employment is the telecommunication sector and especially the call centers because they have the largest number of job offers, and they managed to hire about 6,000 youngers across the country. Even the apparel sector occupies an important place in youth employment and graduates.

\section{Graduates Employment's Models}

Despite the competition that HEl-s can have between them, driven by marketing elements, their most important output with which they must compete are students "who needed to meet market demands". This section will focus on Bridgstock's model for hiring graduates, also USEM model of Yorke and Knight (2006). Then a clear description of the model given to Bezuidenhout (2011), which includes the new demands of the job when considering the employment of graduates.

\section{USEM Model}

This model is supposed to be one of the most accepting and an indicator in terms of employment literature (Pool, L.D. \& Sewell, P, 2007). Yorke and Knight's work is seen to be critical in terms of graduate's employment and how it can be combined with the higher education curriculum. This model suggests the presence of four interrelated components that affect employment.

\section{Model USEM is an acronym of the following ingredients:}

a. Understanding) referring to the critical role of higher education, but is not equivalent to the term "knowledge" that is broader and deeper.

b. Skills that refer to practices capabilities, including not only core traditional meaning of the word "skills", but a broader concept.

c. Confidence in the effectiveness (efficacy beliefs) as a component that differentiates USEM by Bennet (2000). The authors refer Dweck's work, which shows the benefits of a student more flexible than the theorical. These theories characterize a trend that sees tasks as opportunities to learn, and those students who possess these trends are more likely to believe in their ability to operate and the unique and complex challenges.

d. Metacognition is seen as a key element in the employment of graduates, and is known in the literature related to the learning. Yorke and Knight define this term as an inclusion of elements such as: learning how to learn ; reflection of practice; and a capacity of self-Settings.

This model is based largely on research, and is a convenient way of seeing how employment can be expanded. Yorke and Knight (2006) developed a list of 39 aspects of their employment in the project "Skills Plus" which are divided into personal qualities, essential skills, and abilities process.

We can say that USEM model has proven to be very useful in its applications within the field of higher education by providing a strong foundation for students to understand and access the employment. It is very important to prolong the possession 
of learning, which is a necessity in the new world of work. This model allows all parties to understand the concept of the employees and what is required in this regard.

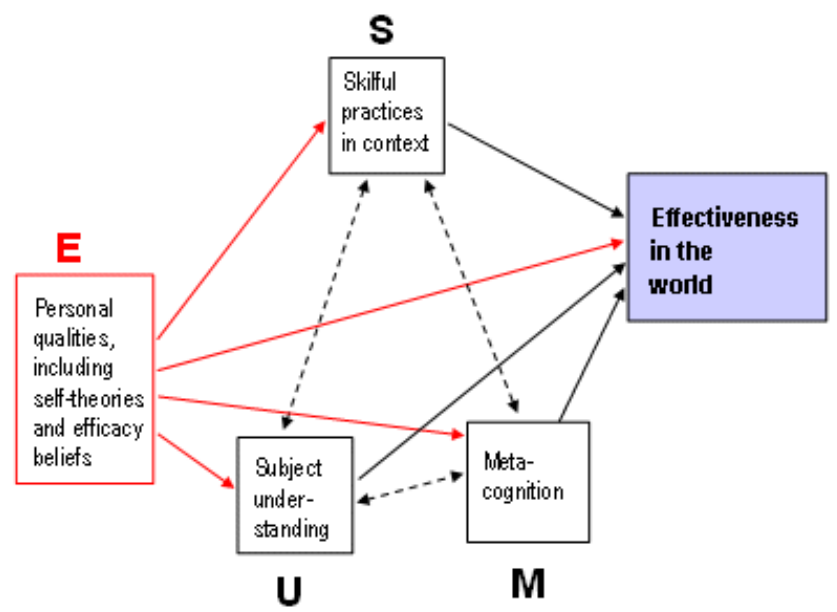

Figure 1. USEM model, Yorke and Knight, 2006, p 5

\subsubsection{Bridgstock's (2009) conceptual model of the attributes of graduates for employment}

The model developed by Bridgstock (2009) proposes that these skills are critical to improve the employment of graduates and the role of career management. Such skills associated with individual perceptions and evaluations regarding the skills, values, interests and goals referred to as self-management skills are closely related to the concept of career identity (Bridgstok, 2009). Bridgstock latter cites the work done by Eby, Butts, and Lockwood, developed in 2003, showing that students who possess a clearly developed concept of their personal career goals and also a positive and a realistic assessment of their capabilities (a strong and well-defined career identity), reported to have a higher level of employment than other students. These building career skills include:

- Knowledge of industry: Students should be informed about the opportunities, threats, and critical success factors associated with their area of expertise. Included here are "knowledge of the rules of the game", industry structure, beliefs, values, and culture, and labor market information (average wages, unemployment rates, and significant economic news).

- The ability to successfully identify and select the best options for the future growth related to the geographical position, projects, and position.

- Being able to identify where should start to see alternative options: This involves the acquisition of new knowledge, training opportunities, and the ability to act quickly once the new opportunities appear.

- Being able to represent themselves and capabilities in a way that every potential employer to see the added value that it has to offer.

- Being able to create personal and professional strategic relationship, as is shown it has a direct effect on hiring real and perceived.

The inclusion of the generic skills of such capabilities in the model is important because literature has proven that these skills are what employers seek to graduates.

Disciplinary skills are those skills that are traditionally incorporated in the curriculum of higher education because the mixture of the generic, self-management and career skills determine the employment. Bridgstok goes on to state that these skills are vital for employment. ". . They play a major role in determining how, to what extent, where and when generic skills, discipline are learned, used (ex. in applying for a job, etc.)". Based on this model, we can say that a graduate who owns them is able to apply for a job. So, more and more heavy weight is given to the needs of career development skills. This is understandable, given the increasing pressure on the largest individuals to assume their responsibilities and career 
development as a result of very rapid change that characterizes today's work environment (Zhiwen, G. \& Van der Heijen, B., 2008).

\subsubsection{Bezuidenhout's model of graduate's employment}

This model is based mainly on the idea of accessibility. Bezuidenhout (2011) defines employment as "a psycho-social construct that represents a combination of attributes (Cut, values, behaviors, and skills) to promote proactive adaptability to the changing environments, to strength employment eligibility of individuals and also to succeed in careers (Bezuidenhout, 2011). It's important to assess the adequacy role in this determination. Specifically dimensions of this model are shown below:

\section{Career self-management}

This is related to the new career styles, which include career with fewer boundaries and variable (Inkson, 2006). De Voest and Soens (De Vos, A \& Soens, N, 2008) made a deep study about the issue and concluded that career self-management makes the difference when it comes to career's success. The is also defined as the creation of opportunities, the setting of goals, and a constant search for new information, which adds an adaptive behavior of each individual employee.

\section{Cultural Competency}

These play an integrated role in the 21-st century, given the global environment in which individuals find themselves. A number of studies have shown that employers evaluate international work experience, and this is a multi-cultural work environment. Therefore, the ability to effectively adapt and understand diversity is one of the core competencies in employment.

\section{Personal particulars}

The model shows how personal trait: self-assessment of career, entrepreneurial orientation, being social, being proactive and open to change can lead to improvements in employment and possibly towards career success.

\section{Self-assessments related essential career}

(Wellman, 2010) cites the work done in 2009 by the Commission for Employment and Skills, which means that more specific knowledgies and technical skills should be added during tertiary studies. Cornford's work in 2005 shows that it's difficult to understand the terminology used to define the employment of graduates. However, those who have generic skills including: communication skills, problem solving, writing on the computer, computer knowledegies, as well as working in a team with others are more likely to compete more successfully in the market. (Ng, P., Abdullah, K., Nee,P. \& Tiew, N., 2009) The primary goal of any institution of higher education is to prepare their students for the working world. As Maher highlights (2004) employers are more interested in what the graduate can do rather than on what he knows. From a survey made by Clarke in 2008 among 40 CEO-s, they said that they were looking for employees that have such attributes as: continuous learning, flexibility, willingness and ability to grow in leadership. Another survey conducted in 2007 by the Institute of Directors in the UK published a list of 28 attributes and the Association of Higher Education (as cited by Wellman, 2010) presented a list of 14 skills required, based on marketing of the graduates as follows:

- Creativity

- Flexibility

- Willingness to learn

- Autonomy at work, etc

There is a broad consensus on the fact that "soft skills" such as leadership skills, negotiation, intrapersonal skills, etc., are critical for any graduate who wants to work in the new world of work, and many employees are becoming more aware of the critical impact of these capabilities in providing a competitive advantage (McQuaid \& Lindsay, 2005). Navarro (Navarro, 2008) argues that these are as important as data analysis and rigorous application of the management and analytic tools. The employees, as well as the recruiters of graduates, constantly emphasize the value of these skills as a soft key in the selection process, but also in maintaining long-term career success. (Pittenger, K.K.S., Miller, M.C \& Mott, J., 2004) 
Yorke and Knight (2006), compiled a list of 39 dimensions of employment, grouped into three categories namely: personal traits, qualities and skills essential procesive. These dimensions were considered useful in the analysis and design of high education curricula. They further citing the work of John Brennan and colleagues considered as primary the following powers:

- Ability to work well in pressure situations

- Communication

- Accuracy

- Attention to detail

- Working in groups

Heyler (Heyler, 2007) is of the opinion that employment is a mix complex of elements that can vary from one position to another. It shows in her work that people need to be adaptable and "multi-functional" as employees and also have the ability to recreate themselves occasionally.

According to (Bowers, M \& Metcalf, M., 2008), graduates today are not adapted to deal with complex uncertainties of the 21 st century, that come as a result of the decentralized organization of the 21st century - the. in most cases, graduates have the technical knowledge but lack the technical skills to use this knowledge Maher (2004) Oxford Brookes University lists five main disadvantages to graduate students for the job market (Zhiwen, G. \& Van der Heijen, B., 2008).

Coping complex situations

Initiative

Lack of tolerance and stress

Excessive Confidence

They support the fact that "soft skills" are not developed enough to graduates. It is clear from this perspective that is a perception that there is a lack of graduates mainly communication skills, which is critical to achieving success at work. (Beaven, Z. \& Wright, R., 2006).

\section{Changes in career graduates}

Until the 1800 s careers were perceived as terms of life-long employment, the mutual loyalty and well defined borders. Small specializations in appropriate jobs were relatively short-lived and foremost for continued employment was the church specific skills for a specific project. (Clarke.M \& Patrickson.M, 2008). This era was short-term, non-specific placements were followed by industrial developments. Economic growth and organizations seeking a new kind of career, instructions and much larger structure returned necessity (Clarke M. , 2008).. As a result workers returned to specialists in their respective positions. The standard was to start in a company, then you were climbing that achieved with hard work, and in return the organization to provide continuous training and job security.

The organization of the 21 st century is characterized by decentralization, fast pace and constant change, and internationalization. These changes are a result of a decline in organizations for being "supportive" by escalating, which has given managers a greater degree of accountability and finally a short term change or a stable contractual agreement. (Harvey L. , 2000). These changes in the environment require more treatments lasting from workers and employers. (Briscoe, J.P., Hall, D.T \& DeMuth, R.L.F, 2006). Not only adaptability and sustainability are strong on the agenda, but accountability for security and personal development already apparently rely solely on the shoulders of workers and moreover to graduates. Reference is made to a new careers, including career and infinite variable. These structures reflect career independence and individual employees do not see themselves more connected to these events, and to some extent the relationship is transactional back somewhat.

Arthur and Rosseu (1996) describe as a career characterized by infinite or free movement between organizations, positions and careers. On the other hand unstable career has to do with the behavior of independent workers, more people become self-governing in managing their careers, and their system of values do be keynote speaker (Briscoe, J.P., Hall, D.T \& DeMuth, R.L.F, 2006).

Some changes that were observed in 1995 with special reference to the work of graduates are as follows:

- a smaller proportion of graduates in traditional graduate jobs. 
- fading career ladders.

- many graduates are becoming self-employed.

- fewer graduates are employed, because most do not have experience.

- concept of life- working is disappearing. (Stewart, J. \& Knowles, V., 1999)

Graduates are now expected to show consistency and ability to work in group projects (Harvey L. , 2000). Stewart and Knowles (1999) assigned to the Association of Graduates Recruitment, in a survey in 1995 to show that today's working world, is characterized by a degree of interaction with customers, giving value to every aspect of work, lifelong learning, career development portfolio, self-development and an extreme need to be employed. Harvey further argues that today's graduates are sought, or rather, expected to "enhance" their jobs within the organization. However, problems related to the "willingness to work", the graduates were the main items around the world and are always-presented to all the participants concerned. (Brown, P., Heskesth, A. \& Williams, S., 2003). It was mentioned that the focus of graduates who are ready to work should be included university attributes that enhance these individuals distinguished in the new world of work, allowing them to work faster productively in their careers. It is widely accepted that each employer has unique requirements for the organization of his / her new employees when required and literature here does not determine which is the list of abilities that can provide employment (Wellman, 2010).

\section{The study}

This paper has considered the questionnaires of about 230 graduates who have finished their studies in public and private universities in Albania during the last five years, among which $55 \%$ were female and $45 \%$ were males. They responded to various questions concerned mainly on the identification of the factors affecting the wages, as well as the key elements that they identify as inherent to their career development. It also measures the average time of the graduates to transfer from university to the workplace.

\section{Purpose}

The main aim of the paper is to highlight the correlation between the wages of the graduates with the number of trainings, with their GPA-s, with the number of foreign languages spoken, with the number of working hours during the week, other personal skills etc..

\section{Findings}

The majority of respondents (39\%) had 1 year or less employed. About $29 \%$ of them were employed as $2-3$ years and $31 \%$ had more than 4 years you worked. Among them only $27 \%$ were only bachelor level, $25 \%$ of their had finished Professional Master, $43 \%$ of them Master of Science, and $6 \%$ of them were with $\mathrm{PhD}$. Half of them (50\%) were specialized in the field of economy. The rest of the respondents had a degree in the field of Law (7\%), of Engineering (19\%), political sciences $(6 \%)$ and the remainder of them were of the teaching field. Most of them said to have attended internships before being employed in current position (62\%). An interesting fact is that half of them admitted that the university where they had finished their studies had helped them to find a work. As resulted from the calculations, the average time of the transition of the graduates from the university to employment was 1.75 years. About $74 \%$ of the respondents were employed in the private sector (most of them in the big businesses) confirming the fact that this sector is still the main generator of employment in the country, $18 \%$ were employed in the public sector and only $9 \%$ were self-employed. However one of the problems observed today, besides the graduates employment, is that of procuring a job that fits with their academic level. Only $68 \%$ of them thought that they had found a suitable working position with their formation. The rest did not think so. According to the the above graduate models studied, respondents replied that they assess more these skills:

\section{Sustainability $38 \%$, Management $32 \%$, Variety $13 \%$, Autonomy: $17 \%$}

Those classified as a major factor of job satisfaction: the work they do (37\%), the opportunities for growth in responsibility and professionally (34\%), secondary factors such as: staff, good willness of the institution, working conditions, etc. (19\%), and the salary $(7 \%)$. They assessed some important elements that they felt had influenced in their employment. As the most important elements that they appreciated were the individual skills, the GPA of their studies, the prestige of the university where they had completed their studies.

They also assessed some important elements of what they thought a graduate should obtain in order to achieve success and career growth, and the element that was identified by them as most important were personal features, the second self- 
career-related assessments, and career self-management and cultural competence recently. They were asked to express their opinion about the causes of the high rate of unemployment of graduates nowadays. Most were of the opinion that the main cause was the unfair competition in the labor market, the large number of students that graduate every year (from public and private universities), the mismatch of the skills that graduates possess and the requirements in the labor market, and the disability of the state / businesses to generate new jobs. Finally they choosed the optimal solution for the financing of higher education in the context of Albania, where the majority (79\%) was for a system funded almost entirely by the state and a small part by the student fees, the other part $(21 \%)$ was pro the transition to a higher education system funded entirely by student fees.

\section{Findings of Regression Analyses}

To estimate the factors that influence on the wages of the graduates in Albania, firstly it has been a division between those who had attended private universities and those who had attended public ones. The explanatory variables included in the model were: the number of trainings and internships, their GPA-s, the number of foreign languages spoken, the number of working hours during the week, and the level of their computer skills. in the first observation, that took in consideration only those who had attended private universities, the results were more significant, $(F[1,141]=13.23 ; R 2=.08, \beta=.11, t[141]$ $=-2.1 ; p<.01)$ more than of those that had attended private universities $(F[1,94]=7.39 ; R 2=.03, \beta=.071, t[94]=-1.7$; $\mathrm{p}<.01)$

\section{Conclusions}

While the above explanation highlights the influence of some quantitative factors that affect salaries, there also other explanations consistent with the results. When graduates are able to impose higher standard of their work, the employers are likely to impose more higher salaries. Accordingly, those individuals who have more productive capabilities, despite their GDP-s or other formation that they achieve from their university, after maintaining and developing their characteristics, are more likely to gain better employment. As it comes out from other studies also, the Albanian graduates must develop better their soft skills, in order to be more efficient in their work and to have the possibility to grow up fast in their career. Our century is characterized by decentralization, fast pace, constant change, and internationalization Every stakeholder must contribute in the future employment of the graduates that finish their every year from our universities. Also is an emergent need, the reforming of higher education in order to reorganize the number of students in each field appropriately with the demand of the labor market. Every student should be aware of the possibilities of employment before choosing the university in which he/she is going to study.

\section{References}

[1] Ama, N. O. (2008). Transition from higher education to e employement: A case study of graduates of faculty of social sciences. ISSN 1990-3839 @ 2008 Academic Journals (pp. 262-274). Educational Research and Review Vol. 3 (8).

[2] Beaven, Z. \& Wright, R. (2006). Employer Attitudes To Arts \& Even Management Graduate Employability. International Journal Of Event Management Reserch, 2, 17-24.

[3] Bezuidenhout, M. (2011). The developemt and evaluation of ameasure of graduate employability in the context of the new world of work. in Unpublished Thesis (p. 78). Pretoria: University Of Pretoria.

[4] Bowers, M \& Metcalf, M. (2008). What employers want and what students need: Integrating business communication into undergraduate business courses. Assocaiation for Business Communication, 1-13.

[5] Bridgstok, R. (2009). The graduate attributtes we've overlooked: enhancing graduate employability through career management skills. Higher Education Resarch \& Developement 28(1), 31-44.

[6] Briscoe, J.P., Hall, D.T \& DeMuth, R.L.F. (2006). Protean and bounderyless careers: an empirical exploration. Journal of Vocational Behavior, 69, 30-47.

[7] Brown, P. H. (2003). Employability in a knowledge- driven economy. Journal of Education and Work, 16 (2), 107-126. 
[8] Brown, P., Heskesth, A. \& Williams, S. (2003). Employability in a knowledge-driven economy. Journal of Education and Work 32(4), 258-284.

[9] Brown, P., Hesketh, A. \& Williams, S. (2003). Employability in a knowledge-driven economy. Journal of Education and Work 16(2), 107-126.

[10] Center for Higher Education Development. (2011). Development of a Ranking in Albania- Final Report. CHE Centre for Higher Education.

[11] Clarke, M. (2008). The new covenant of employability. Empoyee Relations, 121-141.

[12] Clarke, M. (2008). Understanding and managing employability in changing career contexts. Journal of European Industrial Training 32 (4), 258-284.

[13] Clarke, M. (2008). Understanding and managing employability in changing career contexts. Journal of Europian Industrial Training, 32(4), 258-284.

[14] Clarke.M \& Patrickson.M. (2008). The new covenant of employability. Employee Relations, 121-141.

[15] De Vos, A \& Soens, N. (2008). Protean attidude and career success: the mediating role of self-management. Journal of Vocational Behavior, 73, 449-456.

[16] Dias de Oliveira, E. \& de Castro Gulmaraes, I. (2010). Empoyability through curriculum innovation and skills development, a Portuguese case study. Higher Education and Policy, 22(2), 5-8.

[17] EUNACAL. (2012). Studim mbi tregun e punësimit në Shqipëri. EUNACAL INSTITUTE.

[18] Fugate, M \& Kinicki, A.J. (2008). A dispositional approach to employability: developement of a measure and test of impications for employee reactions to organizational change. Journak of Occupational and Organizational Psychology, 81, 503-527.

[19] Graduate Market Trends. (2010, 3 5). Fostering employability skills in postgraduate students practice and research. Retrieved from http://viewer.zmags.com/publication

[20] Green, D. (1994). What is Quality in Higher Education. London: Society for Research into Higher Education.

[21] Harvey, L. (2000). New realities: The relationship between higher education and employment. Tertiary Education and Management, 6 (1), 3-17.

[22] Harvey, L. (2005). Embedding and intergrating employability. New Directions for Institutional Research, 13-28.

[23] Heller, D. (1997). Student price response in higher education. Journal of Higher Education, 68 (6), 624-659.

[24] Heyler, R. (2007). What is empolyability? Reflecting on the postmodern challenge of work-based learning. Journal of Employability in the Humanities, 1, 1-13.

[25] Inkson, K. (2006). Protean and bounderyless careers as metaphors. Journal of Vocational Behavior, 69, 4863.

[26] Kotler, P. \& Fox, K. (1995). Strategic marketing for educational institutions. N.J.: Precentive- Hall: (2-nd edition) Englewood Cliffs.

[27] Lauer, L. (2002). Competing for students, money and reputation: Marketing the academy in the 21-st century. Washington, D.C: Cuncil for Advancement an Support of Education.

[28] Little, B. (2011). Employability for the workers-what does this mean? Education and Training 53(1), 57-66.

[29] McQuaid \& Lindsay. (2005). The concept of employability. Urban Studies, 42(2), 197-219.

[30] Navarro, P. (2008). The MBA core curricula of top-ranked U.D business schools: A study in failure? Academy of Management Learning \& Education, 7(1), pp. 108-123.

[31] Ng, P., Abdullah, K., Nee,P. \& Tiew, N. (2009). Employer's Feedback On Business Graduates: An Exploratory Study in Curtin Sarawak. International Review of Bussiness Research Papers, 5(4), 306-321. 
[32] Pittenger, K.K.S., Miller, M.C \& Mott, J. (2004). Using real-world standarts to enhance students'presentations skills. Business Communication Quarterly, 67(3), pp. 327-336.

[33] Pool, L.D. \& Sewell, P. (2007). The key to employability: developing a practical model of graduate employability. Education and Training 49(4), pp. 277-289.

[34] Psacharopoulos, G. (1987). The Economics of Higher Education in Developing Countries. Comp. Educ. Rev, 139-59.

[35] Rudd, D. \& Mills, R. (2008). Expanding Marketing Principles for the sale of Higher Education. Contemporary Issues in Education Research, 1, 41-52.

[36] Stella, A. (2002). External Quality Assurance in Hlgher Education: Case study of the National Assesment and Accredition Council (NAAC) in International Institute for Educational Planning (HEP). Paris : UNESCO.

[37] Stewart, J. \& Knowles, V. (1999). The changing nature of graduate careers. Career Development International, 4 (7), 370-383.

[38] Tammaro.A.M. (2005). Report on quality assurance models in LIS programs. University of Parma, Italy: Education and training section.

[39] Teichler, U. (2000). Higher Education and Graduate Employment in Europe, New Perspective for Learning. The European Union- Briefing, Paper 10.

[40] Van der Heijden, B. B. (2009). Employability enhancement through formal and informal learning: an empirical study among Dutch non-academic university staff members. International Journal of Training and Developement, 45(3), 449-476.

[41] Van der Heljden, B. (2002). Organizational ifluences upon the development of professional expertise in SMEs. Journal of Enterprising Culture, 9(4), 367-406.

[42] Wellman, N. (2010). Marketing Intilligence \& Planning, 28 (7), 908-930.

[43] Yorke, M. \& Knight, P.T. (2006). Embedding employability into the curriculum. York: The Higher Education Academy.

[44] Yorke, M. (2006). Employability in higher education: what it is- and what it is not. The higher education Academy: Learning and Employability Series No. 1.

[45] Yorke, M. and Knight, P. (2003). Employability in higher education. Retrieved from http://www.heacademy.ac.uk

[46] Zhiwen, G. \& Van der Heijen, B. (2008). Employability enhancement of business graduates. Education \& Training, 50(4), pp. 289-304. 